\title{
LINKAGE BETWEEN FIDGET AND AGOUTI IN THE HOUSE MOUSE
}

\author{
T. C. CARTER \\ Medical Research Council, Institute of Animol Genetics, Edinburgh \\ and \\ H. GRÜNEBERG \\ University College, London
}

INTRODUCTION

Received 20.i.50

THE recessive gene fidget in the mouse (symbol $f i$; Grüneberg, 1943) influences behaviour (head shaking, circling), the cornea and the skeleton (polydactylism and some other effects not yet described). Linkage tests of $f i$ with tan, $a^{t}$, albinism, $c$, and blue dilution, $d$, all gave negative results; there was no close linkage, but the possibility of loose linkage could not be excluded.

During I 949 further breeding records led us independently to suspect loose linkage between $f i$ and $a^{t}$. The combined results, which are presented in this paper, establish its existence ; recombination is about 33.5 per cent. Work is now proceeding to determine the position of $f i$ with respect to that of pallid, $p a$, which is also linked to $a^{t}$ (Roberts and Quisenberry, 1935).

\section{MATERIAL AND DATA}

Two types of mating were used, namely repulsion intercrosses $a+\left|a^{t} f \times a+\right| a^{t} f i$ and coupling intercrosses $A+\left|a^{t} f i \times A+\right| a^{t} f i$; but the progeny of one set of matings of the latter type were divided into three phenotypes with respect to the agouti locus, based on the appearance of the belly (light versus dark) as well as the back (agouti versus black).

The data are shown in table $\mathrm{I}$, which also reproduces those published previously (Grüneberg, I943).

Several other mutants were also present in some of the matings; they were brown, $b$, albinism, $c$, luxate, $l x$, pinkeyed dilution, $p$, and macrocytic anæmia, $W^{v}$. It was not possible to classify fully for pinkeyed dilution, owing to the simultaneous segregation of albinism ; nor was it possible to put any confidence in the classification of luxate, since the double heterozygote $+f i+l x$ was found to resemble the homozygote $l x l x$ and the heterozygote $+l x$ often shows polydactyly similar to that seen in many fidgets. The segregations of $f i$ with $b$, $c, p$ and $W^{v}$ are shown in table 3 . 
T. G. CARTER AND H. GRÚNEBERG

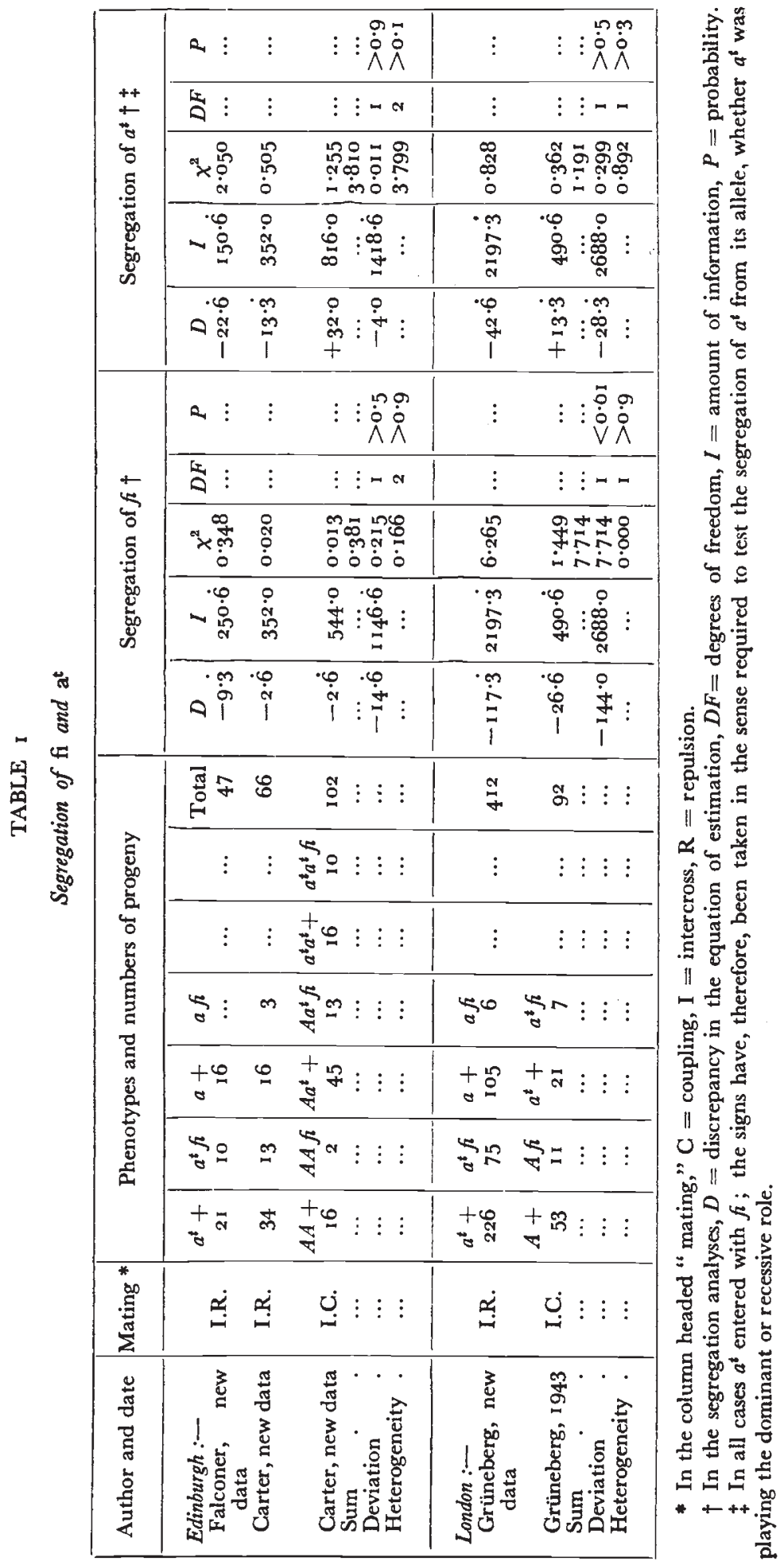




\section{ANALYSIS OF THE DATA}

The data have been analysed by the methods described by Mather (1935, 1937), which are special applications of the maximum likelihood method of estimation (Fisher, 1925). In the linkage analysis, however, we have adopted the sign convention used by Fisher (1946), whereby linkage closer than the trial value is indicated by a positive instead of a negative score.

The single-factor segregation analyses (table I) show a deficiency of fidgets, significant at the I per cent. level, in the London data;

\section{TABLE 2}

Linkage of $\mathrm{fi}$ and $\mathrm{a}^{\mathrm{t}}$

\begin{tabular}{|c|c|c|c|c|c|c|c|}
\hline Author and date & Mating & \multicolumn{6}{|c|}{ Analysis of linkage } \\
\hline $\begin{array}{l}\text { Edinburgh:- } \\
\text { Falconer, new data } \\
\text { Carter, new data }\end{array}$ & $\begin{array}{l}\text { I.R. } \\
\text { I.R. }\end{array}$ & $\begin{array}{r}D_{33} \\
+12 \cdot 685 \\
-7 \cdot 343 \\
-0.672\end{array}$ & $\begin{array}{c}D_{34} \\
+13 \cdot 241 \\
-6 \cdot 278 \\
-6 \cdot 552\end{array}$ & $\begin{array}{c}I \\
55 \cdot 613 \\
106 \cdot 554 \\
3 I \cdot 096\end{array}$ & $\begin{array}{l}\chi^{2} \\
2 \cdot 893 \\
0.506 \\
0.200\end{array}$ & $\begin{array}{l}D F \\
\cdots \\
\cdots\end{array}$ & $\begin{array}{l}P \\
\cdots \\
\cdots\end{array}$ \\
\hline$" \quad$, & I.C. & $-9 \cdot 07^{2}$ & $-0.55^{2}$ & 3 I I 996 & 0.300 & $\cdots$ & $\cdots$ \\
\hline London:- & & & & & & & \\
\hline $\begin{array}{c}\text { Grüneberg, new data } \\
\quad, \quad, \text { I } 943 .\end{array}$ & $\begin{array}{l}\text { I.K. } \\
\text { I.C. }\end{array}$ & $\begin{array}{l}+20 \cdot 200 \\
-27 \cdot 912\end{array}$ & $\begin{array}{l}+30.403 \\
-24.904\end{array}$ & $\begin{array}{l}419.730 \\
300 \cdot 726\end{array}$ & $2.59^{1}$ & $\cdots$ & $\begin{array}{l}\cdots \\
\cdots\end{array}$ \\
\hline $\begin{array}{l}\text { Sum } \\
\text { Deviation } \\
\text { Heterogeneity }\end{array}$ & $\begin{array}{l}\cdots \\
\cdots \\
\cdots\end{array}$ & $\begin{array}{l}\cdots \\
-5 \cdot 976 \\
\cdots\end{array}$ & $\begin{array}{c}\ldots \\
+5.970 \\
\ldots\end{array}$ & $\begin{array}{c}\ldots \\
1194 \cdot 628 \\
\ldots\end{array}$ & $\begin{array}{l}7 \cdot 934 \\
0.030 \\
7 \cdot 904\end{array}$ & $\begin{array}{l}\cdots \\
1 \\
4\end{array}$ & $\begin{aligned} & \cdots \\
> & 0 \cdot 9 \\
> & 0.05\end{aligned}$ \\
\hline
\end{tabular}

Recombination fraction $p=33.5 \pm 2 \cdot 9$ per cent. (standard error).

TABLE 3

Segregation of fi with $\mathrm{b}, \mathrm{c}, \mathrm{p}, \mathrm{Wv}$

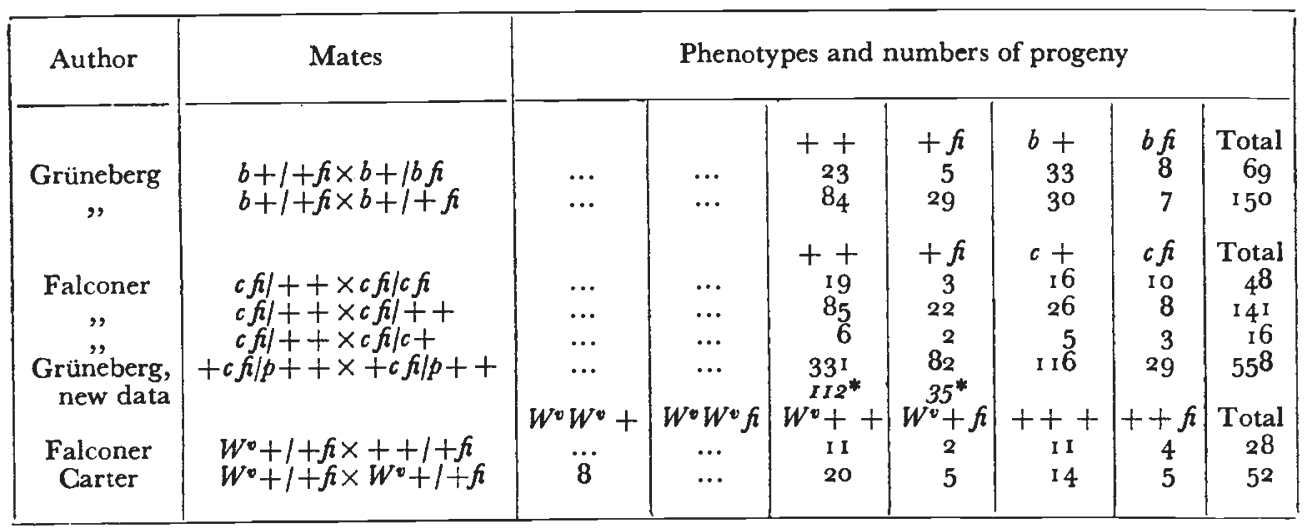

* Figures in italics show the numbers of pinkeyed progeny within the non-albino classes.

the deficiency of $a^{t}$ in the London data is not significant and the Edinburgh data show good segregations at both loci.

In analysing the linkage we assume that the deficiency of fidgets was entirely due to inviability of the homozygotes and that this 
inviability was not dependent upon the genotype at the agouti locus. When these assumptions are made, the estimate of the recombination fraction is independent of the viability of the fidgets : the amount of statistical information available about the estimate is still measured by the rate of change of the discrepancy in the equation of estimation.

The linkage analysis is shown in table 2 : the five bodies of data are homogeneous and indicate linkage with a recombination fraction $33.5 \pm 2 \cdot 9$ per cent. (standard error).

The data of table 3 , which gives the segregations of $f$ with $b, c$, $p$ and $W^{v}$, do not show any significant departures from free segregation.

\section{SUMMARY}

Fidget, $f$, in the house mouse is linked to $\tan , a^{t}$; recombination is estimated at $33.5 \pm 2 \cdot 9$ per cent. Its position with respect to pallid, $p a$, is not yet known.

Acknowledgments.-We are grateful to Dr D. S. Falconer for permission to quote some data from the Animal Breeding and Genetics Research Organisation's laboratory at the Institute of Animal Genetics, Edinburgh. One of us (H. G.) was assisted by a research grant from the Medical Research Council.

Note added and January 1950.-We are grateful to Professor Fisher for pointing out, since this paper was written, that the linkage analysis of some of our data (the four class segregations) could have been facilitated by the use of table $\mathrm{XIV}_{1}$, in the 1948 edition of Fisher and Yates' Statistical Tables for Biological, Agricultural and Medical Research (Edinburgh, Oliver and Boyd).

\section{REFERENCES}

fisher, R. A. 1925. Camb. Phil. Soc. Proc., 22, 700-725.

FISHER, R. A. 1946. Amer. Nat., 80, 568-578.

GRÜNEBERG, H. 1943. J. Genet., 45, 22-28.

MATHER, K. 1935. Ann. Eugen., 6, 399-410.

MATHER, x. 1937. Ann. Eugen., 8, 95-105.

ROBERTS, E., AND QUISENBERRY, J. H. 1935. Amer. Nat., 69, 181-185. 